\section{Distribution of six little known plant species from Arunachal Pradesh, India}

\section{S.S. Dash ${ }^{1} \&$ A.A. Mao ${ }^{2}$}

Botanical Survey of India, Arunachal Pradesh Regional Centre, Itanagar, Arunachal Pradesh 791111, India Email: 1 ssdash2002@yahoo.co.in (corresponding author), 2aamao2001@yahoo.co.in

Arunachal Pradesh being a part of the HimalayaEast Himalaya biogeographic zone (Rodgers et al. 2000) is also the confluence point of three biogeographic realms, namely, the Afro-tropical, the Indo-Malayan and the Indo-Chinese (Takhtajan 1969). It harbours a unique composition of different plant communities, influenced by various factors including rainfall, temperature, humidity and altitude (Biswas 1966). The biodiversity of Arunachal Pradesh is supported by a wide range of endemic species and various fragile ecosystems. More than $82 \%$ of the geographical area of the state is covered with forests, which are the custodians of c. $29 \%$ flowering plants of India (Hajra \& Mudgal 1997).

During the recent floristic survey conducted in the Kurung Kumey District of Arunachal Pradesh, six interesting species were collected which were known only from the type locality. The present collection of these species from areas other than the type localities confirms that they may have a wider distribution in this region. Out of the six species, Dalbergia thomsonii

Date of publication (online): 26 September 2011

Date of publication (print): 26 September 2011

ISSN 0974-7907 (online) | 0974-7893 (print)

Editor: P. Lakshminarasimhan

Manuscript details:

Ms \# 02688

Received 31 January 2011

Final received 13 August 2011

Finally accepted 29 August 2011

Citation: Dash, S.S. \& A.A. Mao (2011). Distribution of six little known plant species from Arunachal Pradesh, India. Journal of Threatened Taxa 3(9): 2095-2099.

Copyright: ( ) S.S. Dash \& A.A. Mao 2011. Creative Commons Attribution 3.0 Unported License. JoTT allows unrestricted use of this article in any medium for non-profit purposes, reproduction and distribution by providing adequate credit to the authors and the source of publication.

Acknowledgements: The authors are grateful to Director, Botanical Survey of India, and Kolkata for encouragement and facility.

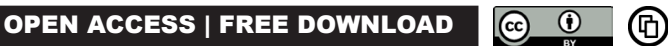

Benth., Larsenianthus assamensis S. Dey, Mood \& S. Choudhury and Plectocomia himalayana Griff. are reported for the first time from the state while Begonia silhetensis (A.DC.) C.B. Clarke, Larsenianthus arunachalensis M. Sabu, Sanoj \& T. Rajesh Kumar and Tricarpelema glanduliferum (J. Joseph \& R.S. Rao) R.S. Rao show extended distribution. These species are provided with the valid name, citation, family name in parenthesis, followd by the specimens studied, a short description, phenology data, critical field notes and photographs for easy identification. The herbarium where the specimens were available are also given in parenthesis. (CAL: Central National Herbarium; ARUN: Herbarium, Botanical Survey of India, Arunachal Pradesh Regional Centre).

1. Begonia silhetensis (A. DC.) C.B. Clarke in Hook, f., Fl. Brit. India 2: 636. 1879; Golding \& Kareg. in Smithsonian Contr. Bot. 60: 233. 1986. Casparya silhetensis A. DC., Prodr. 15(1): 277. 1864. (Begoniaceae)

Specimens studied: Arunachal Pradesh: Abor Hills, I.H. Burkill 37376 (CAL); Kurung Kumey District: On way from Sangram to Koloriang, S.S. Dash 31223 (ARUN); NEFA (Kameng), G.Panigrahi 6029 (CAL).

Succulent herbs with tuberous, fibrous rootstock. Stem 35-90 cm high, glabrous. Leaves obliquely ovate-cordate, 16-28 x 13-22 cm, glabrous, glaucous and whitish beneath, shaggy on both surfaces, base broadly cordate, margins finely denticulate, often glandular at dentate tips, apex acute or acuminate, broadly palmately veined with 7-8 further forked midribs; stipules ovate, $1-1.5 \mathrm{~cm}$ long, apex acuminate; petioles $15-50 \mathrm{~cm}$ long, glabrous or occasionally covered with whitish hairs, often purple tinged. Inflorescence in scapes, 5-12 cm long. Flowers unisexual. Male flowers: white or pinkish-white; sepals two, oblanceolate or oblong-ovate, $1-1.8 \times 0.8$ $1.5 \mathrm{~cm}$; petals usually two, occasionally $3-10$, cyclic; stamens numerous, yellowish. Female flowers: sepals and petals similar to male flowers; styles bifid, connate at base. Fruits globose, $1.5-4.5 \mathrm{~cm}$ across, glabrous to densely brownish hairy, often variegated.

Flowering \& Fruiting: January-June. 


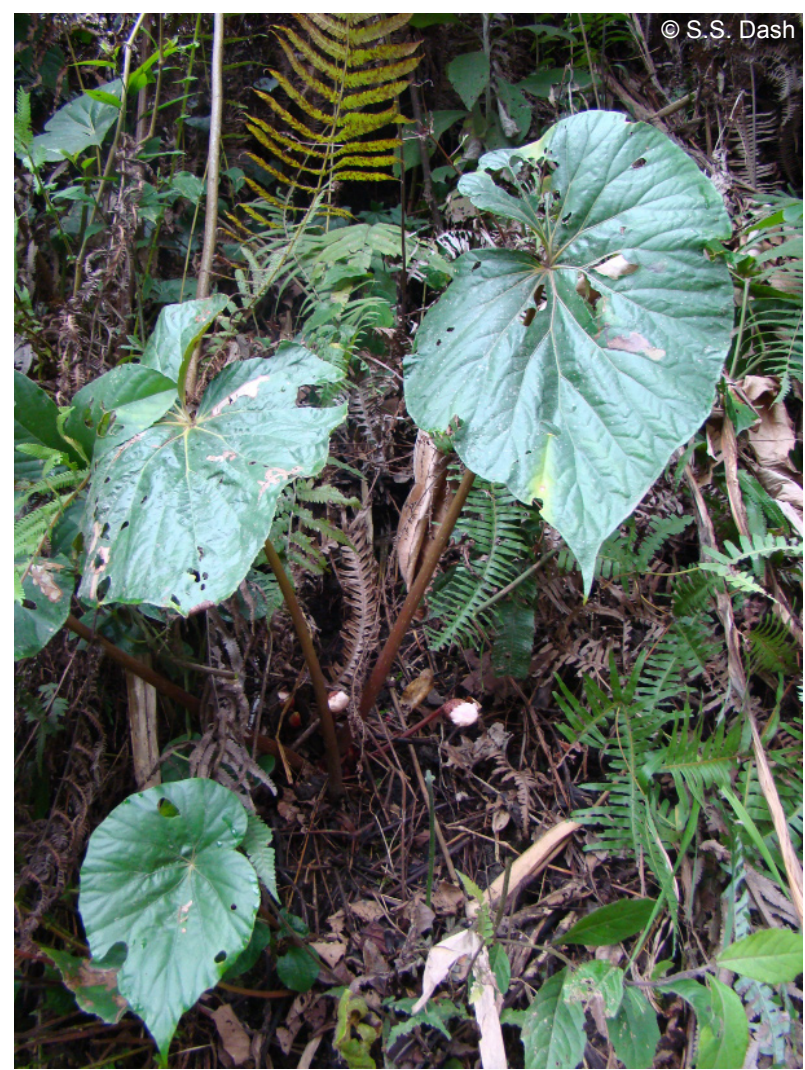

Image 1. Begonia silhetensis (A. DC.) C.B. Clarke

Ecology: Found in gregarious patches on forest floors, moist and damp grounds of primary forests, $800-1500 \mathrm{~m}$.

Notes: After type, this species was first collected by I.H. Burkill from the Abor Hills of Arunachal Pradesh on 24.xi.1911 and was known only from its type locality till it was recollected from Kameng District of Arunachal Pradesh on 24.iii.1957 by G. Panigrahi. While exploring the Kurung Kumey District, the species was again collected and a good population was found scattered along the primary forest floors.

2. Dalbergia thomsonii Benth. in J. Linn. Soc. Bot. 4 (Suppl.): 33.1860; Baker in Hook. f., Fl. Brit. India 2: 236. 1876; Sanjappa, Legumes India 141. 1992. Amerimnon thomsonii (Benth.) Kuntze, Revis. Gen. P1. 1: 159. 1891. (Leguminosae-Papilionoideae)

Specimens studied: Arunachal Pradesh: Kurung Kumey District: Kurung River to Yangtey, S.S. Dash 32834 (ARUN); Lower Subansiri District: Yazali, G.D.Pal 1265 (ARUN); West Siang District: on way to Kane Wildlife Sanctuary, S.S. Dash 32280 (ARUN).

Large woody climbers. Stem glabrous; branchlets lenticellate. Leaves $10-15 \mathrm{~cm}$ long, petioles terete; leaflets imparipinnate, oblong-elliptic or elliptic, 2-3.5 x 1-2 cm, glabrous on both surfaces, base cuneate or rounded, margins entire, apex emarginate; lateral veins 7-8 pairs, prominent beneath; petiolules 3-4 $\mathrm{mm}$ long, terete; stipules 4-5 mm long. Inflorescence in axillary and terminal panicles, corymbose at first; branches ascending and ultimate becoming scorpioid. Flowers deciduous; bracts acuminate. Calyx minutely pubescent, unequally 5-lobed; upper 2-lobed, rounded at apex, connate at base; lower 3-lobed. Petals pinkishwhite; standard suborbicular or elliptic-obovate, 7-10 x 5-8 mm, emarginate at apex; wings oblong; keels boat shaped. Anther filaments unequal, connate with a sheath at base. Pods greenish, narrowed at base, strap shaped, 5-10 x 2.5-4 cm, indehiscent, glabrous. Seed one.

Flowering \& Fruiting: July-January.

Ecology: Found occasionally in the primary dense forests, $400-1200 \mathrm{~m}$.

Notes: Dalbergia thomsonii Benth. is endemic to Assam, Meghalaya and Tripura (Kumar \& Sane 2003). This species was first collected from Arunachal Pradesh by G.D. Pal from Yazali of Lower Subansiri District and wrongly identified as Dalbergia assamica Benth. [synonym of Dalbergia lanceolaria L.f. var. assamica (Benth.) Thoth.]. The species was again collected by one of us (SSD) from subtropical primary forests of Kurung Kumey and West Siang districts. Dalbergia thomsonii Benth. can be differentiated from the other climbing species of the genus Dalbergia of Arunachal Pradesh by the presence of emarginate elliptic leaves, axillary and terminal panicled inflorescence which are initially corymbose later becoming ascending scorpioid.

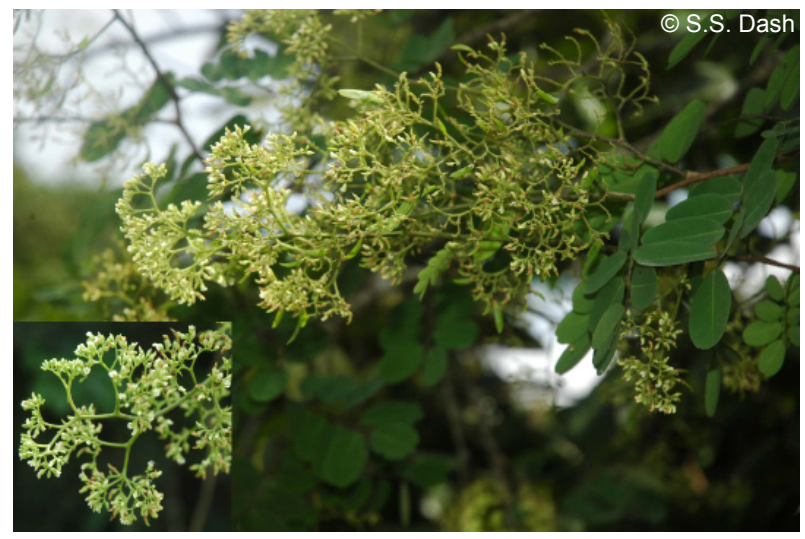

Image 2. Dalbergia thomsonii Benth. 
3. Larsenianthus arunachalensis $\mathrm{M}$. Sabu, Sanoj \& T. Rajesh Kumar in PhytoKeys 1: 28, fig 4 \& P1. 1D. 2010. (Zingiberaceae)

Specimens studied: Arunachal Pradesh: Kurung Kumey District: along the Wabia River, on way to Parlo, S.S. Dash 31721 (ARUN).

Herbs, $1-1.5 \mathrm{~m}$ high. Rhizomes c. $1.9 \mathrm{~cm}$ across, hard, fibrous, slightly aromatic, inner colour pale brown. Leaves 2-4 per flowering shoot, elliptic-oblong, 35-75 $\times 11-18 \mathrm{~cm}$, base narrowly attenuate, margins entire, apex finely acuminate; lateral veins depressed below; basal leaf sheath red, glabrous; petioles $15-25 \mathrm{~cm}$ long, glabrous; ligules lanceolate $6-12 \times 2-2.5 \mathrm{~cm}$, glabrous, apex attenuate. Inflorescence terminal on leafy shoots, erect, 25-65 cm long; spikes elliptic, 11-15 x 3-4 cm; floral bracts deep red, spirally arranged and closely imbricate, orbicular to broadly elliptic, $2-2.7 \times 2.5-$ $2.8 \mathrm{~cm}$, coriaceous, glabrous, apex acute; bracteoles tubular, longer than bracts. Flowers conspicuous, 2-4 per bract. Calyx tubular, pale red, white towards base, 1.4-1.6 cm long, glabrous, apex trilobed; floral tube red, $3.2-3.3 \mathrm{~cm}$ long; dorsal lobe reflexed, sparsely pubescent; lateral lobes glabrous. Lateral staminodes orbicular to broadly elliptic, pinkish-white; labellum red to creamy yellow towards base, $20-25 \times 2.5-3$ $\mathrm{mm}$; fertile stamens red; anthers creamy-yellow, arching like a fish-hook. Ovary trilocular; stigma white, bulbous, margins ciliate, exserted.

Flowering \& Fruiting: July - September.

Ecology: Occasionally found in dense and extremely moist primary forests, $1200-1500 \mathrm{~m}$.

Notes: This species was recently described by Sabu et al. from Lohit District of Arunachal Pradesh (Kress et al. 2010) and was known only from the type locality. While surveying the Kurung Kumey District, the species was collected by one of us (SSD) from a single locality where c. 150 adult plants were growing. The occurrence of this species in Kurung Kumey District shows that the species might have a wider distribution in the state. It is interesting to note that the specimens collected from Kurung Kumey District differ from the protologue by its complete nature of glabrousness. Studies on the herbarium specimens as well as live plants in the field, could not confirm the hairy nature of leaf ligules, pubescent nature of the leaf lamina with silvery hair, twisting condition of the leaf apex and pubescent nature of the floral bract as mentioned in the protologue.

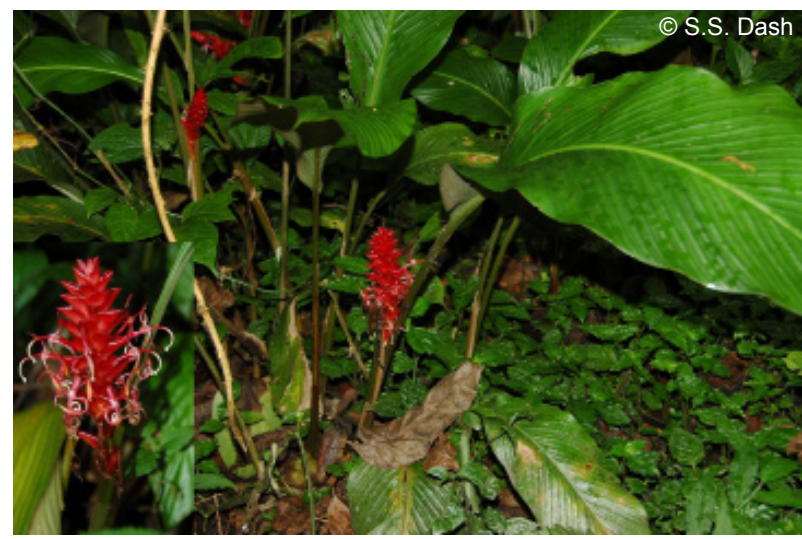

Image 3. Larsenianthus arunachalensis M.Sabu, Sanoj \& T. Rajesh Kumar

4. Larsenianthus assamensis S. Dey, Mood \& S. Choudhury in PhytoKeys 1: 26, fig.3 \& Pl. 1C. 2010. (Zingiberaceae)

Specimens studied: Arunachal Pradesh: West Siang District: on way to Kane Wildlife Sanctuary, S.S. Dash 32218 (ARUN).

Rhizomatous herbs, $60-80 \mathrm{~cm}$ high. Leaves oblong-lanceolate or elliptic-lanceolate, $20-35 \times 5-7$ $\mathrm{cm}$, glabrous above, glaucous beneath, base narrowed to a leaf sheath, margins entire, apex finely acuminate; leaf sheaths $5-11 \mathrm{~cm}$ long, drying brown, whitish inside; ligules bilobed. Inflorescence terminal, usually on a reflexed peduncle, erect, 7-9 x 3-8 cm, glabrous; involucral bracts deep red, $3-4 \times 0.7-1 \mathrm{~cm}$, acuminate at apex; floral bracts overlapping, closely clasping to each other, 2-3 x 0.8-1.3 cm, conspicuously veined. Flowers white, 1-3 per bract. Calyx tubular. Corolla lobes linear-lanceolate; lobes conspicuous. Staminodes reddish, ovate, with a reflexed labellum of $2-2.5 \mathrm{~cm}$ long; fertile stamens whitish, light orange outside arched at base, oblong. Ovary trilobed.

Flowering \& Fruiting: July-September.

Ecology : Occasionally found in the primary dense forests, 300-700 m.

Notes: This species was recently described from Barail Wildlife Sanctuary, Cachar District, Assam by Dey et al. and was known only from two locations in the sanctuary (Kress et al. 2010). The present collection from the Kane Wildlife Sanctuary (West Siang District) establishes northern extension of the species and its first record for the state of Arunachal Pradesh. During the survey, only 10-15 plants were observed in the field. 


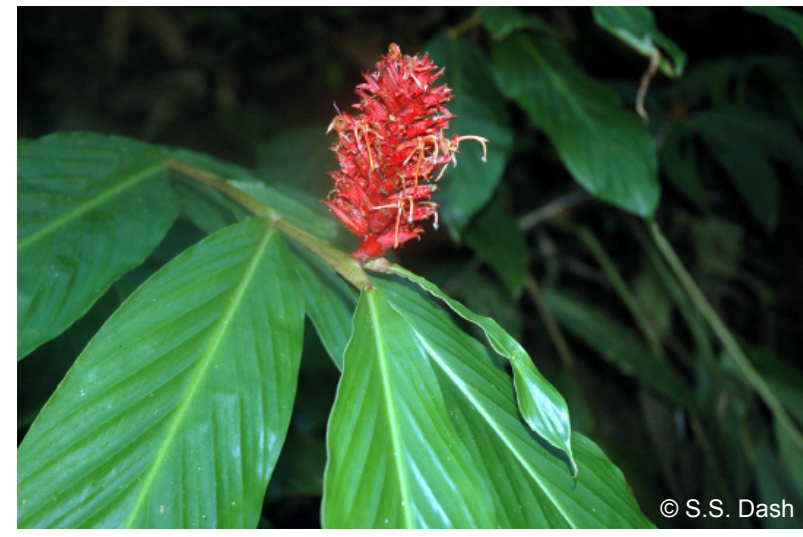

Image 4. Larsenianthus assamensis S.Dey, Mood \& S. Choudhury

5. Plectocomia himalayana Griff. in Calcutta $\mathrm{J}$. Nat. Hist. 5: 100.1845; Karthik et al., Fl. Ind. Enum. Monocot. 21. 1989; Govaerts \& J. Dransf., World Checklist Palms 180. 2005. (Arecaceae)

Specimens studied: Arunachal Pradesh: Kurung Kumey District: Miri to Yangtey, S.S. Dash 31341(ARUN).

Scandent shrubs. Stems up to $20 \mathrm{~m}$ long, ascending. Leaf sheaths tomentose, densely spiny; spines straight, arranged in wavy manner, oblique at mouth. Petioles very short, often clasping to stem. Leaves $2-3.5 \mathrm{~m}$ long; pinnae linear-lanceolate, narrowed to a long filiform cirrate apex; rachis flattened, tomentose, lower part sometimes spiny, upper part heavily armed with recurved spines (grapnels). Male rachis zigzag; bracteoles minute; inflorescences axillary; peduncles drooping, covered with densely overlapping floral bracts broadly ovate or rhombic, 4-5 cm long, apex acuminate; calyx tubular, finely tomentose outside, apex acuminate. Fruits globose, spherical, reddishbrown on maturity.

Flowering \& Fruiting: August-March.

Ecology: Common in dense subtropical forests, 500-2000 m.

Notes: This species is distributed from Nepal to China (Yunnan). In India it was known to occur in Sikkim. The present collection from Kurung Kumey District forms the basis for the first report of its distribution in Arunachal Pradesh. Vegetatively, the species is easily confused with the scandent species of Calamus in wild, but can be differentiated by the presence of sharp spines on wavy lamellae, long filiform leaf tips, drooping inflorescence and rachilla

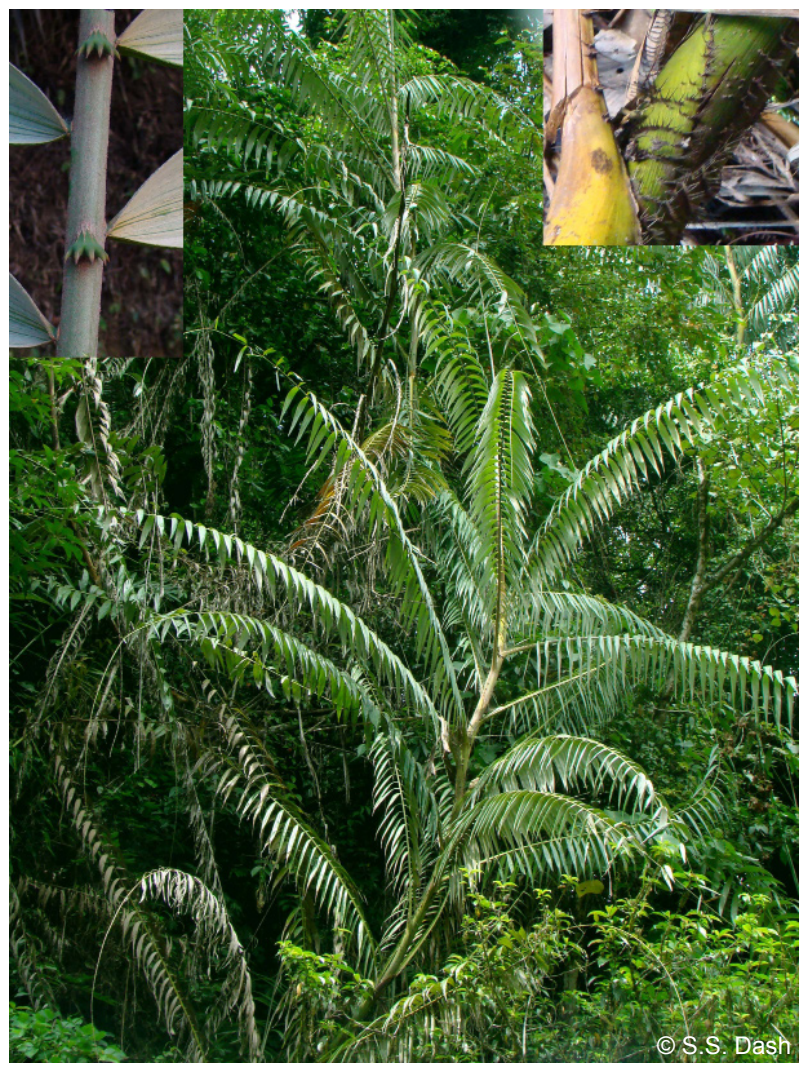

Image 5. Plectocomia himalayana Griff.

often hidden by broad bracts. Traditionally the pith of this species is used as fodder and the stem fiber is used for making houses and baskets by the Nishi tribe.

6. Tricarpelema glanduliferum (J. Joseph \& R.S. Rao) R.S. Rao in J. Indian Bot. Soc. 59 (Suppl.): II(III). 1980; Karthik. et al. Fl. Ind. Enum. Monocot. 31. 1989; Faden in Novon 17: 167. 2007. Aneilema glanduliferum J. Joseph \& R.S. Rao in J. Indian Bot. Soc. 47: 367. 1969. (Commelinaceae)

Specimens studied: Arunachal Pradesh: Kurung Kumey District: near Palin, S.S. Dash 31334 (ARUN).

Herbs. Stems up to $85 \mathrm{~cm}$ high, puberulous or glabrous. Leaves lanceolate, $11-17$ x 1-5 cm, upper surface papillose-hispid, hispid only on veins beneath, finely acuminate at apex, hispid-ciliate at margins, narrowed to very short petiole-like base; sheaths widely cylindric, 2.2-3 cm long; upper leaves almost overlapping. Inflorescence $5-17.5 \mathrm{~cm}$ long, densely glandular-pubescent, terminal; bracteoles leaving scars; flowers borne near ends of branches; pedicels $1-1.5 \mathrm{~cm}$ long. Flowers pale mauve to bright blue. 


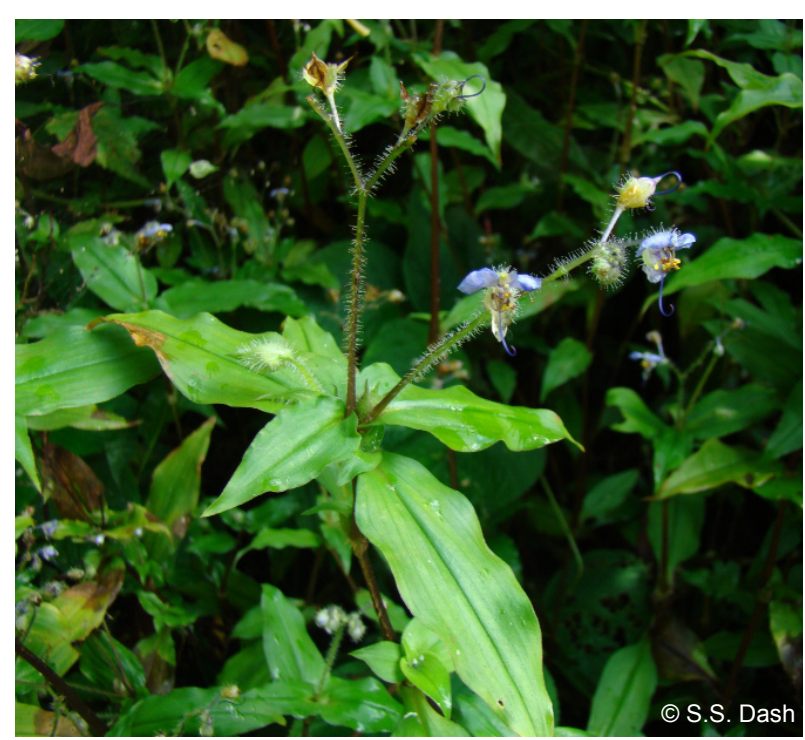

Image 6. Tricarpelema glanduliferum (J. Joseph \& R.S. Rao) R.S. Rao

Sepals oblong-elliptic, margins scarious, apex hooded, 4-5 x $3 \mathrm{~mm}$, glandular-pubescent. Petals obovate, rounded, c. $6 \times 5 \mathrm{~mm}$. Ovary narrowly ellipsoid, c. 3 $\mathrm{x} 1 \mathrm{~mm}$, tapering upwards into style, glabrous; style c. $9 \mathrm{~mm}$ long, filiform, twisted at apex. Fruiting branch stout, upward curving, each bearing single capsule. Capsule segments narrowly oblanceolate.

Flowering \& Fruiting: July-October.

Ecology: Scattered along river banks or stream sides, 700-1800 m.

Notes: Tricarpelema glanduliferum (J. Joseph \& R.S. Rao) R.S. Rao is known to occur in India (Arunachal Pradesh) and Vietnam. This species was described from Kameng District of Arunachal Pradesh. Tricarpelema glanduliferum is very similar to Tricarpelema giganteum (Hassk.) H. Hara which occurs commonly in Eastern Himalaya. However, the former species can be differentiated from the latter by the presence of multicellular glandular hairs in inflorescence and pedicels. Due to their close morphological similarity, either of the species is often overlooked by the collectors, unless both the species are in flowering condition. The present collection of this rare species made on 08 September 2009 from Arunachal Pradesh after a lapse of 46 years after type collection from an area other than the type locality also confirms occurrence of this species in India.

\section{REFERENCES}

Biswas, K.P. (1966). Plants of Darjeeling and the Sikkim Himalayas.Government Press, Calcutta, 540pp,

Hajra, P.K. \& V. Mudgal (1997). Diversity in Hotspots - An Overview. Botanical Survey of India, Calcutta, 1-12pp

Kress, W.J., J.D. Mood, M. Sabu, L.M. Prince, S. Dey \& E. Sanoj (2010). Larsenianthus, a new Asian genus of Gingers (Zingiberaceae) with four species. PhytoKeys 1: 15-32.

Kumar, S. \& P.V. Sane (2003). Legumes of South Asia. Royal Botanic Gardens, Kew, p.176.

Rodger, W.A., H.S. Panwar \& V.B. Mathur (2000). Biogeographical Classification of India in Wildlife Protected Area Network in India: A Review (Executive Summary). Wildlife Institute of India, Dehra Dun, 49pp.

Takhtajan, A. (1969). Flowering Plants, Origin and Dispersal. Edinburgh: Oliver \& Boyd, 310pp. 